\title{
RESENHA
}

\section{GEOSSISTEMAS: A HISTÓRIA DE UMA PROCURA}

Carlos Augusto de Figueiredo Monteiro

Difícil dizer neste livro se estamos diante de uma autobiografia acadêmica ou de um trabalho sobre o método da pesquisa em Geografia. Fácil é ver que Carlos Augusto de Figueiredo Monteiro não é um de nossos maiores geógrafos por favor ou acaso. Síntese de uma prática de vida, Geossistemas: a história de uma procura resume toda a experiência de pesquisa e magistério superior desse geógrafo brasileiro.

A busca da categoria estruturante, seja na edificação do discurso e seja na prática do método, é um tema que atravessa as indagações dos geógrafos ao longo de todos os tempos. E atravessa também o texto de Carlos Augusto.

No plano geral de um saber diferenciado em natureza e homem (temas tomados como respectivos da Geografia Física e da Geografia Humana), a resposta unitária veio com a categoria da região. Foi a época em que o dilema Geografia Sistemática versus Geografia Regional preenchia páginas e páginas de argumentações contra e a favor desta ou daquela vertente. Um desencontro que contudo sempre se resolvia na convergência dos fenômenos para o contexto unitário da categoria da região, numa espécie de concordância de uma certa neutralidade teórica. Mesmo quando de categoria unitária a região era transformada numa Geografia Regional (então proclamada "a verdadeira geografia" e frente à qual a Geografia Sistemática era mera linha auxiliar). Ainda assim, e por conta da universalidade da região, a Geografia Regional agia como o campo da unidade da Geografia Física e da Geografia Humana, tomadas como os dois grandes campos de diferenciação da Geografia Sistemática.

Metodologicamente, esta unidade vinha por conta da categoria da paisagem. Confundida com o processo da classificação dos fenômenos, num papel proeminente do método taxonômico que a Geografia foi buscar ao método científico oitocentista, chamado período da representação clássica por Foucault, a paisagem unificava os dados físicos e os dados humanos, num ensaio de uniformidade de olhares que ía facilitar, para além, a constituição da unidade global de ambos campos através da síntese regional.

É este percurso na teoria e no método geográficos e sua resposta final na categoria do geossistema, uma categoria de análise integrada em Geografia, o itinerário do livro de Carlos Augusto. Levado com mãos experientes e seguras, o leitor, espero que profissionais calejados e estudantes universitários em princípio de carreira, pois todos temos a ganhar com a leitura desse livro, acompanha a história dessa procura, do momento centrado na paisagem ao da centração da teoria e do método da Geografia no geossistema, no que acaba por ser uma reconstituição de uma das experiências de teoria e método mais ricas que a geografia brasileira teve.

O detalhamento do método de pesquisa é primoroso. Operando com uma combinação de cartogramas, transetos e matrizes de correlação, característica de toda a prática do geógrafo Carlos Augusto de Figueiredo Monteiro, desde quando este inicia sua trajetória acadêmica, e uma propriedade do conceito de geossistema, o método de pesquisa do autor, fartamente enriquecido de ilustrações ao longo do livro, é dos mais estimulantes. Dir-se-ia que Carlos Augusto sempre dispôs da solução de muitas das perguntas de teoria e método que insistentemente vimos fazendo. 
O desfecho, para quem imagina de um "geógrafo físico" uma apologia corporativista, é surpreendente.

A lamentar, a edição descuidada. As ilustrações necessitam de uma reimpressão em maior escala, talvez em página dupla, o que permitirá melhor visualização e leitura das indicações de categorias (ninguém consegue ler nomes e legendas nos cartogramas, transetos e matrizes de correlação, o que limita ao extremo a assimilação e proveito do método de pesquisa e trabalho do autor). Até porque, esta é uma obra que, desde agora, será de uso obrigatório nos cursos universitários e escritórios de pesquisa de geografia em todo o Brasil.

A esperar, que outros geógrafos do nível do autor ouçam e atendam seu desejo de igual pronunciamento. A geografia brasileira agradeceria imensamente.

(Ruy Moreira) 